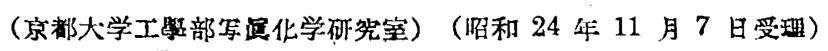

(160) ソラリゼーションの機構に関する䂪究（第 3 報）

粒子內に於ける潜像の分布に就て

笹井明

\section{I. 緒 言}

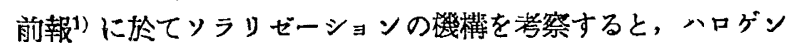
銀粒子內の潜像銀の分布が異ならねばなら奴ら、これを研究す ることが一つの重要な問題と考えられることを述へた。そこで潜 像の粒子內に於ける分布をBerg 等2) と同様の考えによつて試驗 し,ソラリゼーション部に於ける潜像銀の分布及び変化を貺明し 得るンラリゼーションの僟構を考察することとした。

\section{2. 実 驗 方 法}

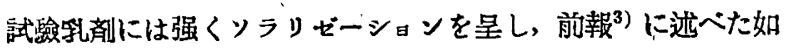
き特徽のある No. $4 \mathrm{~A}$ 及び No. $4 \mathrm{C}$ を用いた。但し乳剂彆造 のゼラチンは BN-29を使用した。

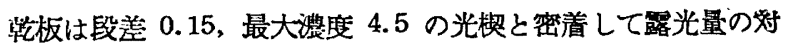
数 2.7, 露光時間 10 秒と露光量の対数 4.5 , 露光時間 10 秒々 のン種の露光を行つた。郎ち照度変化の露光を行つた。

粒子の表面に潜像を持つ具化銀を現像するには, 露光後直ちに D 72 現像液の鹠硫酸ソーダを 3 分の1に減したもので現像した (素面潜像の現像)。この見像液は主として表面潜像の現像を行う ものであつて，鈇塩現像液はより完全な表面潜像の現像腹と認め られるが，鉄塩現像液は理論的研究以外実際には全く用いられな いから前報との比較考察の篇主藥の相巽をさけて一般的な D 72 を用いた。(鉄塩現像液による笑簽は別に報告する予定)

粒子表面の潜像を除去するには露光後現像前に重クロム酸カリ の $0.25,0.5,1,5,10 \%$ の各液を用いて $18^{\circ}$ で 5 分処理した。 表面潜像を除去した後內部潜像を現像するには，現像前に $2 \%$ のハイボ溶液（0.1\%の亞硫酸りーダを含む）で 30 秒，1分， 5 分, 10 分処理し或は $2 \%$ のシアン化カリで 30 秒， 1 分， 3 分処理し、粒子內部の潜像を表面に裸出させてから水洗した後前 記 D 72 現像液で現像した。內部潜像を現像するにBerg 等は八 イボを添加したメトールハイドロキノン現像液が適することを逝 ベているが，著者は $\mathrm{Nafe}^{4)}$ 及び Webb5)のハイボ処理によりッ ラリゼーションが消失する垁騟と此绞考察したいと考元臭化銀溶 凨で処理後 D 72 で現像する等とした。

尚比較の爲に簬光後ハイボヌはシアン化カリで処理し現像した 物, 重クロム酸カリで処理後現像したもの，ハイボヌはシンン化 カリで処理した後重クロム酸カリで処理し現像したものをも試踤 した。

\section{3. 重クロム酸カリ処理の影響}

露出後現像前に䆙クロム酸カリ溶液にて处理すると第 1 図の如 く溧い液を用いたもの程画像瀑度か低下寸る。この結果は表面の

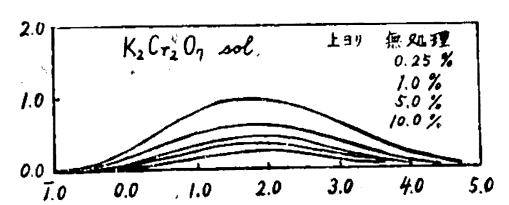

潜像が重クロム酸カリによつて破塯された結果と视められる。潜

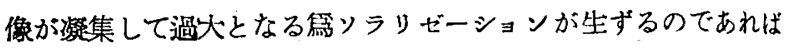
Arens ${ }^{6)}$ の行つた定着後の潜像に対するつァーマー減液の作用

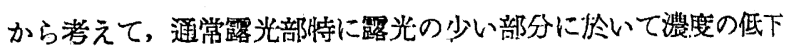
が多く、ソラリゼーション部は瀑度の低下が少くなる筈であると

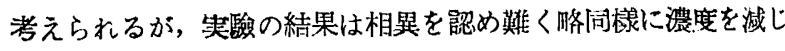
ている。

\title{
4. ハイポ処理の影響
}

露出後現像前にハイポ溶液で处理すると第 2 园の如く通常蕗光 第 2 図

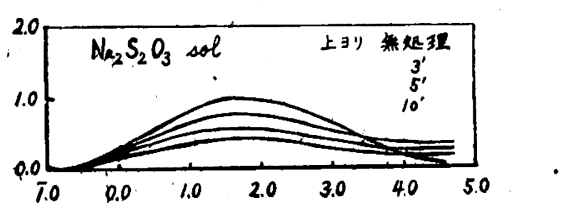

域では潜度を減じ最大瀑度も減少して粒子が一部溶解する第濃度 が減少することを示す。然しソラリゼーション域では濃度の減少 が少く强くソラリゼーションされた部分の濃度はハイボ处理によ つて增加し反枟は弱められる。Nafe ${ }^{4)}$ Webb方)によればハイボ 処理によつて反転か消失すると報告されているが本実剑では反输 が弱められるだけで消失はしなかつた。

この現象はソラリゼーションされた粒子がハイポ処理によつて 現像性を得ることを示し，再臭化貺によれば再臭化により潜像表

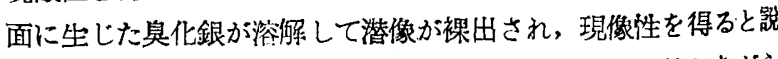
明され再臭化說を支持する有力な事笑とされている。然しながら 著者は粒子表面の潜像が渦大露光によつて現像性を失つたが， イボ処理によつて粒子內部の別の潜像か新たに裸出された学現像 されたとみれば疑等說でも說明されるから必ずしも再臭化貺に有 利にはならないと考える。

\section{5. シアン化カリ処理の影非}

ハイボが臭化鎾溶㓮として以外に特別の作用をしていると云う 疑があるので八イボの代りに具化銀溶倣としてシアン化カリを用

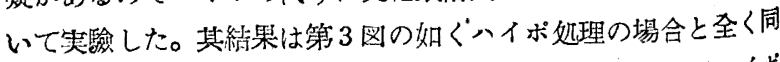

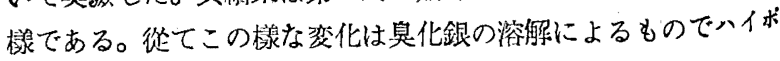


第 3 圀

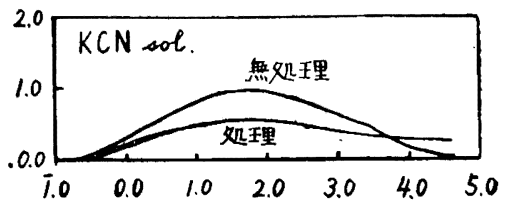

の硫化銀生成作用の如き他の作用は関係ないものと考えて艮いで あろう。

\section{6. 重クロム酸カリ処理後ハイポにて 処理し現像した場合}

重クロム酸カリで処理し水洗した後ハイボに浸漬しその後水洗 して現像すると，第4図の如くハイボ処理をしないで現像した場 合よりも濃度が高く, 重クロム酸カリ処理せずにハイボ処理をし

第 4 自

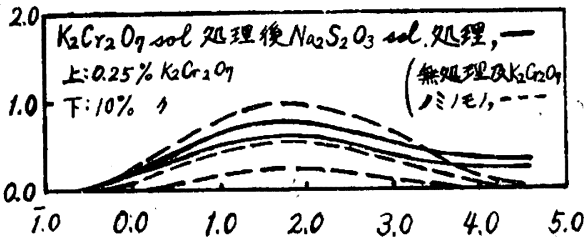

て現像した場合と大差ない結果が得られる。從つてこの場合ハイ ボは粒子內部の潜像を表面に裸出させ活性にすると認められる。 重クロム酸カリ処理後ハイポ処理したものが單にハイボ处理した 場合と比較して余り差がないから重クロム酸カリの $0.25 〜 10 \%$ で処理しても粒子內部の潜像は殆ど影響を受けないと考えられハ イボ処理を行うとソラリゼーション部に於いて特に濃度が墂加す るから，ソラリゼーション部には內部潜像が多いことが制る。

\section{7. ハイポにて処理後重クロム酸カリで処理した場合}

$2 \%$ ハイホにに 3 分処理した後重クロム酸カリにて処理すると 第5 図の如く, 重クロム酸娌によ゙つて澧度が減じ潜像が破寝ざ

$$
\text { 第 } 5 \text { 図 }
$$

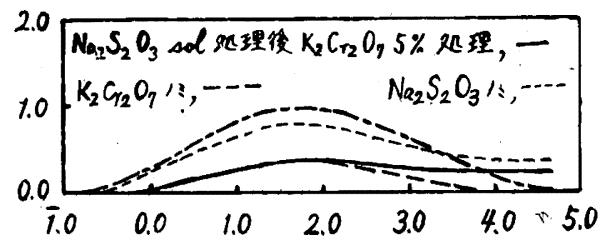

れるのが認められる。この結果を重クロム酸カリ処理のみのもの と比較すると露光の少い部分では大差がないが，ソラリゼーショ ン部では效度が高くなつている。ハイポ処理後の重クロム酸カリ の影鈅は, 露光の多いソラリゼーション部程少いから, ハイポ処 理後表面にある潜像刨ち內部潜像が露光の多いとき程重ク口ム酸 カリに破懐され難いことが知られる。再具化によつて表面をおお われていた潜像が破懷され難いと考えるか，或は凝集した表面潜 像とは別に粒子內部の潜像があり，この內部潜像が露光大なる部
程破壤され難いものと解しなければならぬ。しかしながら電ク口 ム酸カリ処理のみのときは,ソラリゼーション部の潜像が特に破 猿され難くはないから粒子の表面にある潜像銀はソラリゼーショ ン部に朎いて特に大型ではないものと考えられ，ハロゲン銀が過 大䠰光を受けたとき表面の潜像銀は小さいが粒子㐫部の潜像銀が 大型であると推察される。從つて粒子表面の潜像銀が影光と共に 登達し，潜像銀はそのまま表面にあるが過大となつて現佛促䔨作 用を減小する第, 反転を生ず.ると考える從來の凝集證とは多少矛 盾することとなる。

從つて著者はハロゲン銀粒子が露光を受けると粒子の表面及び 內部に光銀郎ち潜像銀を生じるが，普通の現像の際には殆ど表面 潜像銀のみが関係し，路光が多くなるとこれらの潜像銀は何れも 增大寸ると共に互に㠜集して大型となりこれと同時に表面潜像銀 の特に発達せるものは露光によつて遊離されたハロゲンと反応し て再ハロゲン化されて表面がハロゲン銀によつておおわれる爲, 現像促進作用を失つて表面潜像銀は大型の內部潜像銀に饻化する と洘える。この際潜像銀の凝集と丽ハロゲン化とは各々独立に行 われ，凝集の結果は定着後の物理現像に於ける反転の原因となり 再ハロゲン化が普通化学現像のソラリゼーションの原因となると 考えられる。郎ち潜像銀をハロゲン銀粒子の表面にあるものと內

/ 部にあるものとに分けて，その潜像の銀溶剤に対する作用と現像 促進作用とを考えると，化学現像に於けるソラシゼーションを凝 集說で說明すると矛盾を生じ，表面潜像銀の衣面の再ハロ ゙゙ン化 によるものと考えねば證明され難い。

\section{8. 総括}

ソラリゼーションを呈し易き乳剤にて乾板を製し、この乾板を

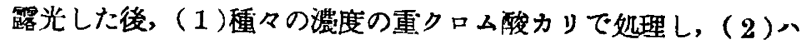
ロゲン銀溶剤で処理し（（3)重クロム酸カリ液にて処理後ハイボ 溶液で処理し，或は（4）八イボ処理後電ウ口ム酸カリ液にて処 理し，それぞれ現像してぞの影響を調へたたその結果はハロゲン 銀粒子內に於ける浲面潜像と內部潜像の露光量による墰減及び潜 像銀の大きさに就いて教察すると，ソラリゼーション部に於いて は表面潜像は少く且つ小さく，內部潜像銀が大きく且つ多いと考 えなければならない。

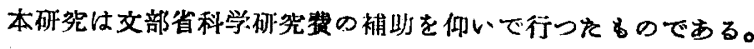
一引用交献

1) 筑井明, 工化, 52, 8, 10(1949).

2) W. F. Berg, A.Marriage, G.W.W.Stevens, J.Opt. Soc. Amer. , 31, 385(1941) ; Phot. J., 81,413(1941)

3) 钽井明, 工化, 52, 8, (1949)；日本写的学会誌，11， 24(1948).

4) J.E.Nafe and G.E.M.Jauncey, Phys. Rev., 57, 1048(1940).

5) J.H.Webb, J.Opt. Soc. Amer., 30, 445(1940).

6) H.Arens, Z. wiss. Phot., 30, 127(1931). 